\title{
Fabrication of Hydropump
}

\author{
Pramod Mahajan', Kiran Harnale ${ }^{2}$, Akshay Jadhav ${ }^{3}$, S.T Dhande ${ }^{4}$ \\ ${ }^{1,2,3}$ People's Education Society's College of Engineering, Nagsenvana, Aurangabad-431002 (M.S.), India \\ ${ }^{4}$ Professor, People's Education Society’s College of Engineering, Nagsenvana, Aurangabad-431002 (M.S.), India
}

\begin{abstract}
As we know that river water current has some velocity in the range 0.5-5m/s it poses an amount of kinetic energy \& also the obvious need for agriculture is water, which is required to be pumped from river. So it is seems a good idea to pump that water by using the hydropower from the same river without any special construction. So we decided to put that idea in actual practice. The moving water rotates the wheel or turbine, which spins a shaft. The motion of the shaft can be used for mechanical processes, such as pumping water, or it can be used to power an alternator or generator to generate electricity. The use of hydrokinetic energy to pump the water for agriculture fields is very economical
\end{abstract}

Keywords: Waterwheel, Hydropower, Pump, Head, Agriculture

\section{Introduction}

It is a typical type of pump which is used to pump the water without electricity. The main purpose of our project is use of Hydropump in Agricultural field.

Another major application of impoundment hydropower is pumped storage. In contrast to conventional hydropower plants which release water after it generates power, pumped storage plants reuse water after it initially produces electricity. Typically, the water flows from the turbines into a second, lower reservoir located below the dam. During offpeak hours (i.e., periods of low energy demand), some of the water is pumped back to the upper reservoir and released to generate electricity during periods of peak energy demand.

\section{Literature Survey}

1. Water Power: the Undershot Waterwheel and Pelton Wheel Collections Department Museum of Science \& Industry

Waterwheels first appeared in Egypt in around 200 BC. These early waterwheels were aligned horizontally and could be powered by oxen. They were used to raise water to irrigate the land and to power millstones for grinding grain into flour. Their use quickly spread throughout the Mediterranean. The Romans brought waterwheel technology to Britain. By 1086 when the Domesday Book was produced, there were more than 5,000 waterwheels in England. These would have been vertical waterwheels, featuring a right-angled gear system, which were much more efficient than the horizontal waterwheel.

Before the development of the steam engine in the eighteenth century, many industries relied on the water power to drive their machines. Using cast iron instead of wood enabled the manufacture of more powerful and durable waterwheels. However, waterwheels were an unreliable source of power, because of the possibility of drought or flood, and were soon surpassed by the steam engine. The undershot waterwheel is the simplest type of waterwheel. It consists of a paddle wheel that is placed so that it is about a quarter submerged in the river. The wheel is turned by the force of the water current against the submerged paddles.

During the dry season, the level of the waterfalls and the river flows more slowly, supplying less power to the waterwheel. Undershot waterwheels are wholly reliant on the energy of flowing water. The other types of waterwheel, the overshot waterwheel and breast shot waterwheel are more efficient because they harness the force of gravity as well as the water energy. The overshot waterwheel is positioned so that water flows onto the top of the wheel.

\section{Design and Performance Analysis of Centrifugal} Pump, Khin Cho Thin, Mya Mya Khaing, and Khin Maung Aye.

This paper deals with the design and performance analysis of centrifugal pump. In this paper, centrifugal pump is analyzed by using a single-stage end suction centrifugal pump. Two main components of a centrifugal pump are the impeller and the casing. The impeller is a rotating component and the casing is a stationary component. In centrifugal pump, water enters axially through the impeller eyes and water exits radially. The pump casing is to guide the liquid to the impeller, converts into pressure the high velocity kinetic energy of the flow from the impeller discharge and leads liquid away of the energy having imparted to the liquid comes from the volute casing.

A design of centrifugal pump is carried out and analyzed to get the best performance point. The design and performance analysis of centrifugal pump are chosen because it is the most useful mechanical rot dynamic machine in fluid works which widely used in domestic, irrigation, industry, large plants and river water pumping system. Moreover, centrifugal pumps are produced by manufacturing processes in Myanmar.

In this paper, the pump is driven by one horse power electric motor and the design is based on Berman Method. The head and flow rate of this pump are $10 \mathrm{~m}$ and $0.179 \mathrm{~m} 3 / \mathrm{s}$ and the motor speed is $2900 \mathrm{rpm}$. The low specific speed is chosen because the value of specific speed is 100 . The number of impeller blade is 9 blades. The performance analysis of centrifugal pump is carried out after designing the dimensions of centrifugal pump. So, shock losses, impeller 


\section{International Journal of Science and Research (IJSR) \\ ISSN (Online): 2319-7064}

Index Copernicus Value (2013): 6.14 | Impact Factor (2015): 6.391

friction losses, volute friction losses, disk friction losses and recirculation losses of centrifugal pump are also considered in performance analysis of centrifugal pump.

\section{Methods/Approach}

\subsection{Concept}

The basic concept is, run a water wheel by means of flow of river water current $\&$ use that power for pumping the water.

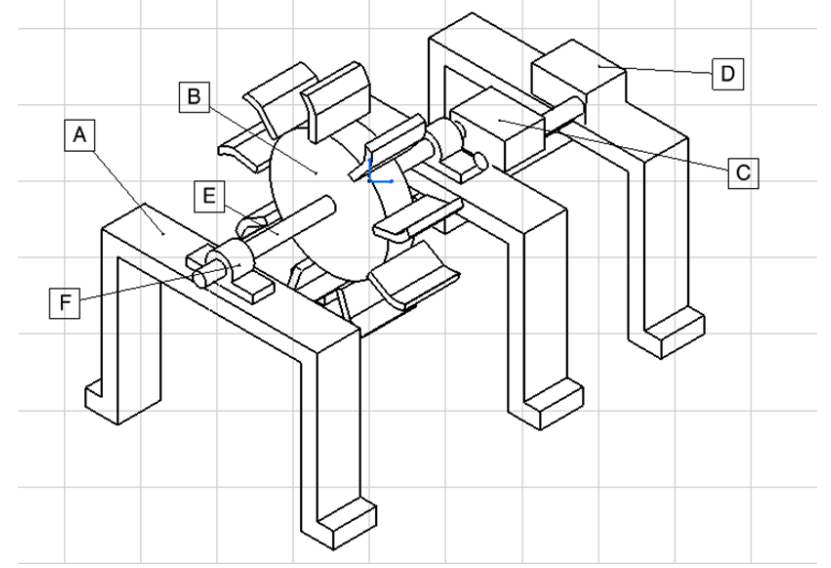

A- Foundation

B- Water wheel

C- Gear box

D- Impeller

E- Main shaft

F- Pedestal housing for bearing

We design this particular assembly to run the impeller of

0.5hp (373watt) pump.

\subsection{Design of water wheel}

Design of water wheel contains design of blades, its angle, depth \& no of blades.

\subsubsection{Angle of deflection}

For maximum o/p, the water should strike the blades at an angle of $90^{\circ}$. From geometry of water fall at site, we found the angle of deflection is to be $165^{\circ}$.

\subsubsection{No. of blades}

For water wheels, No. of blades are found from geometry of water fall. By considering the fact that, only one blade should have contact with the flow stream. So the angle between two blades is $40^{\circ}$.

Then no of blades $=\frac{360}{40}$

$=9$ nos.

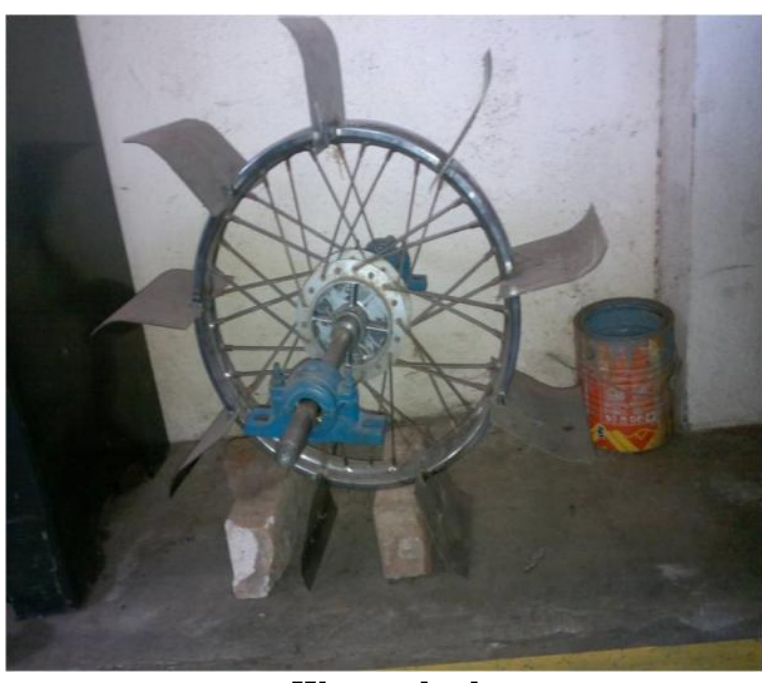

Water wheel

\subsection{Design of main shaft-}

Assuming the power o/p of $1 \mathrm{kw}$ to be transmitted with 40 rpm.

Then torque to be transmitted is given by,

$$
\begin{aligned}
& \mathrm{T}=\frac{60 \times 10^{6} \times 1}{2 \pi \times 40} \\
& \mathrm{~T}=238.73 \mathrm{~N}-\mathrm{m}
\end{aligned}
$$

Value of ${ }^{\tau}$ for M.S. material is taken as $100 \mathrm{~N} / \mathrm{mm}^{2}$. Diameter of shaft is calculated from equation,

$\mathrm{d}=22.65 \mathrm{~mm}$

$$
\tau=\frac{16 T}{\pi d^{\mathrm{s}}}
$$

$\approx 25 \mathrm{~mm}$

\subsection{Design of gear box}

From trials we have the rpm of main shaft as $65 \mathrm{rpm}$, with the power o/p as 1169 watt. So by considering, various losses we decided to run the impeller by $1440 \mathrm{rpm}$.

Consider a loss of 10rpm when wheel is loaded Then i/p rpm $=55 \mathrm{rpm}$

Output $\mathrm{rpm}$ required $=1440 \mathrm{rpm}$.

$$
\text { V.R. }=\frac{1440}{55}=25.35
$$

We design the gears to achieve this rpm in two stages to reduce the size of gears.

$\therefore$ V.R. in each stage $=\sqrt{25.35}$

$=5.08$

We can select a gear pair of $25 \& 127$. Which has a V.R. $=5.08$.

So, rpm of impeller shaft $=1456.35 \mathrm{rpm}$

\subsection{Design of Intermediate Shaft}

Torque transmitted by intermediate shaft $=\frac{238.73}{5.08}$ $=47.73 \mathrm{~N}-\mathrm{m}$ 


\section{International Journal of Science and Research (IJSR) \\ ISSN (Online): 2319-7064}

Index Copernicus Value (2013): 6.14 | Impact Factor (2015): 6.391

Value of ${ }^{\tau}$ for M.S. material is taken as $100 \mathrm{~N} / \mathrm{mm}^{2}$.

Diameter of shaft is calculated from equation,

$$
\begin{aligned}
& \mathrm{d}=13.37 \mathrm{~mm} \\
& \approx 15 \mathrm{~mm}
\end{aligned} \quad \tau=\frac{16 T}{\pi d^{\mathrm{s}}}
$$

\subsection{Bearing Selection}

\subsubsection{Selection of bearing for main shaft}

Shaft diameter, $\mathrm{d}=25 \mathrm{~mm}$

For mounting, we used adapter sleeve of i.d. $25 \mathrm{~mm} \&$ o.d. $30 \mathrm{~mm}$

$$
\therefore \text { Bearing i.d. }=30 \mathrm{~mm}
$$

Radial load on bearing, $F_{r=723.43 \mathrm{~N}}$

$$
L_{10=8446.64 \text { million rev. }}
$$

$\therefore$ dynamic load carrying capacity, $\mathrm{C}=F_{r} \times\left(L_{10}\right)^{\frac{1}{s}}$

$$
\begin{aligned}
& =723.43^{\times} \times(8446.64)^{\frac{1}{8}} \\
& =14733.53 \mathrm{~N}
\end{aligned}
$$

So we can select bearing having designation 1206, which has dynamic load carrying capacity, $\mathrm{C}=19500 \mathrm{~N}$

\subsubsection{Selection of bearing for intermediate shaft:}

Shaft diameter, $\mathrm{d}=15 \mathrm{~mm}$

$$
\therefore \text { Bearing i.d. }=15 \mathrm{~mm}
$$

Radial load on bearing, $F_{r=135.01 \mathrm{~N}}$

$$
L_{10}=146.4 \text { million rev. }
$$

$\therefore$ Dynamic load carrying capacity, $\mathrm{C}=F_{r} \times\left(L_{10}\right)^{\frac{1}{s}}$

$$
\begin{aligned}
& =135.01^{\times(146.4)^{\frac{1}{s}}} \\
& =5590.2 \mathrm{~N}
\end{aligned}
$$

So we can select bearing having designation 6202, which has dynamic load carrying capacity, $\mathrm{C}=7800 \mathrm{~N}$

\section{Result / Discussion}

\subsection{Results}

For finding out the rpm of main shaft $\&$ the power output from it, we took no of trials. The results are discussed as follows.

\subsubsection{Results of first trial}

Rpm of wheel shaft $=52 \mathrm{rpm}$

Work done $=296.47$ watt

\subsubsection{Results of second trial}

Rpm of wheel shaft $=65 \mathrm{rpm}$

Work done $=1169.06$ watt

\subsubsection{Results of final trial}

Rpm of wheel shaft $=65 \mathrm{rpm}$

Rpm of intermediate shaft $=65 \mathrm{rpm}$

Head available $=9 \mathrm{~m}$

Discharge $=0.165 \mathrm{lit} / \mathrm{sec}$

\subsection{Discussion on results}

After first trial, we had a power output at water wheel shaft 296.47 watt. Which is not sufficient to run the pump of $0.5 \mathrm{hp}$ (i.e. 373 watt). So we modify water wheel $\&$ took a second trial. At that time we had a power approximately 1169 watt, which was more than sufficient to run the pump of $0.5 \mathrm{hp}$, by considering all the losses \& efficiencies.

After the final trial we got results as discussed above.

\subsection{Estimation of payback period}

Table 1: Estimation of payback period

\begin{tabular}{|c|c|c|c|}
\hline $\begin{array}{c}\text { Sr. } \\
\text { No. }\end{array}$ & Cost category & $\begin{array}{c}\text { Conventional } \\
\text { electric pump }\end{array}$ & Hydropump \\
\hline 1 & Initial cost in Rs. 'I' & 2,800 & 13,550 \\
\hline 2 & $\begin{array}{c}\text { Running cost in Rs./month } \\
\text { 'R' }\end{array}$ & 900 & 0 \\
\hline 3 & $\begin{array}{c}\text { Maintenance cost/year 'M' } \\
54\end{array}$ & $\begin{array}{c}5 \% \text { of initial } \\
\text { cost }=140\end{array}$ & $\begin{array}{c}10 \% \text { of initial } \\
\text { cost }=1355\end{array}$ \\
\hline 5 & $\begin{array}{c}\text { Cost after 1 year= } \\
\text { I+( }\left(\mathrm{R}^{*} 12\right)+\mathrm{M}\end{array}$ & 13740 & 14905 \\
$=13740+\left(\mathrm{R}^{*} 4\right)+(0.5 * \mathrm{M})$ & 17410 & 15582.5 \\
\hline
\end{tabular}

From above analysis it is clear that, the payback period of Hydropump is around $\mathbf{1 6}$ months.

*The above analysis was done by assuming the fact that; the pump is running for 24 hours each day.

\section{Conclusion}

From above results \& analysis, it is seen that, the use of hydrokinetic energy to pump the water for agriculture fields is very economical. Though the initial \& implementation cost of this project is more than conventional pump, but it recovers by the zero running cost. The payback or recovery period for 24 hour running $0.5 \mathrm{hp}$ pumps is found to be 16 months i.e. after 16 months, the use of Hydropump is totally cost free. Only small maintenance cost is required. In spite of above advantages, it also possible to run the pump of more power, by increasing the diameter of water wheel or mounting the no. of water wheels on the main shaft.

The site selection becomes the key factor in designing this types of projects. It's because the site should have the required flow characteristics with the feasibility of installation \& maintainability. If the site is feasible for installing, then use of Hydropump gives an uninterrupted \& economical output.

\section{Acknowledgement}

We are extremely thankful and express our sincere gratitude to our guide Prof. S.T. Dhande, Whose enthusiastic and ever helping attitude helped us a lot to make this endeavor a success.

We also take this opportunity to thank Dr. M.M. Dhobe, H.O.D. Mechanical Engg. and all lecturers for inspiring \& helping us in very possible way. 
We are also thankful to Mr. Ravi Shirolkar \& Mr. Shivaji Kadam for their kind \& whole hearted co-operation without which this project would have been only a dream.

\section{References}

[1] U.S. Energy Information Administration, Electric Power Annual, Summary Statistics for the United States, 1997 through 2008, Table ES1, http://www.eia.doe.gov/cneaf/electricity/epa/epates.html.

[2] DOE has identified approximately 5,677 sites with the potential to generate about $30 \mathrm{GW}$ of power using smallscale hydroelectric technologies. U.S. Department of Energy, Office of Energy Efficiency \& Renewable Energy ,Hydropower Resource Potential, DOE 2006, http://www1.eere.energy.gov/windandhydro/hydro_potent ial.html.

[3] Low-head hydropower usually refers to sites with a head (i.e., elevation difference) of less than five meters (about 16 feet). Sites with less than three meters (about 10 feet) of head are generally referred to as "ultra-low head."

[4] International Energy Agency, Hydropower Implementing Agreement, Hydropower Frequently Asked Questions, http://www.ieahydro.org/faq.htm\#a4.

\section{Author Profile}

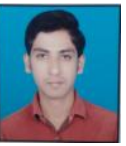

Pramod Mahajan - received the Diploma in Mechanical Engineering from T.B.G. Polytechnic, Ambajogai (M.S.) in 2013, and pursuing B.E. in Mechanical Engineering.

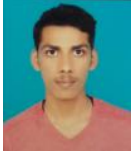

Kiran Harnale- pursuing B.E. in Mechanical Engineering from P.E.S. College of Engineering, Aurangabad.

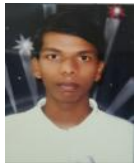

Akshay Jadhav - pursuing B.E. in Mechanical Engineering from P.E.S. College of Engineering, Aurangabad.

Prof. S.T Dhande- assistant professor in P.E.S Engineering College, Aurangabad. 